\title{
Development of the value chain and supply chain for MiPymes of the municipality of Mixquiahuala de Juárez Hidalgo to generate networks of mutual collaboration
}

\author{
Desarrollo de la cadena de valor y cadena de suministro para las MiPymes del \\ municipio de Mixquiahuala de Juárez Hidalgo para generar redes de colaboración \\ mutua
}

\author{
RODRIGUEZ-AGUILAR, Raquel†ं, GARCÍA-ROJAS, Jesús Alberto, CRUZ-ÁLVAREZ, Arminda \\ and LÓPEZ-HERNÁNDEZ, Karla Linive
}

ID $1^{\text {st }}$ Author: Raquel, Rodriguez-Aguilar

ID 1st Coauthor: Jesús Alberto, García-Rojas / ORC ID: 0000-0002-0292-0789, Researcher Thomson ID: I-9224-2018

ID $2^{\text {nd }}$ Coauthor: Arminda Cruz-Álvarez

ID $3^{\text {rd }}$ Coauthor: Karla Linive, López-Hernández.

DOI: $10.35429 / J B S .2019 .16 .5 .20 .36$

Received June 22, 2019; Accepted December 30, 2019

\begin{abstract}
The present investigation intends to follow up the results of the activities that are part of the work previously carried out by the academic body of the Superior Technological Institute of the West of the State of Hidalgo, which was to identify the current situation of the economic development of MSMEs of the municipality of Mixquiahuala de Juárez Hidalgo, as these are the largest economic impact in the region and as the strategic management and use of information and communication technologies, as well as the tools and methods they used, in order to detect opportunities for improvement and propose alternative solutions based on this information. Therefore, thanks to the results obtained from the previous study, we intend to manage the collaboration networks through a model of the value chain, as well as one of the supply chain using the affected mechanisms, which affects their development. Another important point was the necessary elements for the creation of both the value chain and the supply chain since both depended on its turn and size because while some companies need certain specific areas, others do not, due to their characteristics. Thanks to their creation, the aim is to achieve the growth of MSMEs on the one hand, and on the other the management of the collaboration networks among themselves.
\end{abstract}

Online and offline market, Technology, Economy

\begin{abstract}
Resumen
La presente investigación tiene la finalidad de darle seguimiento a los resultados de las actividades que forman parte del trabajo realizadas anteriormente por el cuerpo académico del Instituto Tecnológico Superior del Occidente del Estado de Hidalgo, la cual fue identificar la situación actual de desarrollo económico de las MiPymes del municipio de Mixquiahuala de Juárez Hidalgo, por ser estas las de mayor impacto económico en la región y como aplican la gestión estratégica y el uso de las tecnologías de información y comunicación, así como las herramientas y métodos que utilizan para ello, a fin de detectar oportunidades de mejora, y proponer alternativas de solución basadas en esta información. Por lo cual gracias a los resultados obtenidos del estudio anterior, se pretende gestionar las redes de colaboración mediante un modelo de la cadena valor, así como uno de cadena de suministro utilizando los mecanismos adecuados, que permitan el desarrollo de las mismas. Otro de los puntos importantes que se consideraron a favor, fueron los elementos necesarios para la creación tanto de la cadena de valor, como la cadena de suministro, pues ambas dependerán tanto de su giro, como de su tamaño, ya que mientras algunas empresas necesitan de ciertas áreas esencialmente, otras no, debido a las características de las mismas. Gracias a la creación de éstas se aspira a lograr por un lado el crecimiento de las MiPymes, y por otro la gestión de las redes de colaboración entre ellas mismas.
\end{abstract}

Cadena de valor, Cadena de suministro

Citation: RODRIGUEZ-AGUILAR, Raquel, GARCÍA-ROJAS, Jesús Alberto, CRUZ-ÁLVAREZ, Arminda and LÓPEZHERNÁNDEZ, Karla Linive. Development of the value chain and supply chain for MiPymes of the municipality of Mixquiahuala de Juárez Hidalgo to generate networks of mutual collaboration. Journal of Bussines and SMEs. 2019. 5-16: 20-36

$\dagger$ Researcher contributing first author. 


\section{Introduction}

The importance of creating and developing Micro, Small and Medium Enterprises (MSMEs) is to be taken into consideration within any economy, since their contributions have become an excellent means to promote the economic and social development of a region, contributing with a better distribution of its resources and wealth; besides, they are the largest generators of jobs (above large corporations) contributing with certain stability to the labor market (Gómez V. , 2007) In our country, in particular, it is necessary to highlight the importance of the SMEs since, together with the microenterprises, they represent more than $99 \%$ of all companies, that is: 2,899,196 microenterprises, 101,003 small and 27,319 medium enterprises, while they are 19,996 large companies. (H., 2007)

In Hidalgo, there are 21245 companies, $99.94 \%$ are MSMEs, and the remaining $0.06 \%$ are large enterprises, as in the rest of the country. The problem of MSMEs lies in the lack of competitiveness in both markets, local, national and international, to allow the survival and consolidation of a favorable position. About eight years ago the town started to see the arrival of renowned shopping centers (Bodega Aurrera, Coppel, malls, Oxxo, 3b, etc.) which are the main competition for small businesses in Mixquiahuala, so it is necessary to involve collaboration networks; this means that the local MSMEs join together to work for a common goal, which in this case would be to make their profits grow through the mobile application called "PYME ONLINE" as a competitive advantage to make orders online and sent to the homes. This is done in order to revive the market and thus help the Mexican economy since the vast majority of these commercial chains are of foreign origin, increasing their foreign earnings, rather than the Mexican economy. (Cordero, 2009)

A company's value chain is part of a more extensive system of activities that encompasses the value chains of its suppliers and those of any partner in the distribution chain involved in delivering the product to the end-users. Supplier value chains are relevant because suppliers perform activities and incur costs to create and deliver the inputs acquired and used in the company's value-creating activities.
A company's value chain activities often have a close link to the value chains of its suppliers and their partners in later stages of distribution or the customers to whom they sell. The Supply Chain is a chain of suppliers, factories, warehouses, distribution centers, and retailers through which raw materials are purchased, processed, and shipped to the customer.

Supply chain management encompasses the planning and management of all supplyrelated activities, procurement and conversions of all activities. It also includes the coordination of partners who may be intermediary suppliers, suppliers and customers. In general, supply chain management integrates supply and demand within and across companies. (David, 2008)

The supply chain is all the parties involved in the manufacturing processes of the products or services, whether in direct or indirect ways. The supply chain is not only about producers and suppliers but also about stocks, processors, wholesalers and retailers, even the customers themselves. The supply chain involves the reception and delivery to the final customer, i.e. all the processes followed to reach the final product. Throughout the development of the article we will address how the product will reach the customer considering the application that will be used.

\section{Literature revisión}

When starting with the value chain, we begin by identifying two sources that are essential for its development: cost leadership and differentiation, where, according to Porter, these two depend on all those activities that take place in the company.

The value chain is a succession of actions carried out to install and enhance the value of a successful product or service in a market through a viable economic approach.

Any company or association, valuecreating organization wishing to improve its competitiveness can achieve its objectives if it is based on the value chain. It is a precious strategic management tool, as it acts in the positioning of a product or service in the market. 
It has three objectives:

The improvement of services.

The reduction of costs.

The creation of value.

This model, in fact, allows interested organizations to successively analyze all of their activities with the aim of improving each stage as much as possible in order to constitute and optimize a competitive advantage. (Robben, 2015) The chain begins with the supply of raw materials and continues throughout the production of parts and components, manufacturing and assembly, wholesale distribution and so on until it reaches the end user of the product or service.

A generic value chain consists of three basic elements:

Primary Activities are those related to the development of the product, its production, logistics and commercialization, and post-sales services.

The Support Activities to the primary activities are composed of the administration of human resources, purchases of goods and services, technological development (telecommunications, automation, process development and engineering, research), business infrastructure (finance, accounting, quality management, public relations, legal advice, general management).

The margin, which is the difference between the total value and the total costs incurred by the company to perform the value-generating activities.

The primary activities of the business, which consist of:

a. Incoming logistics: made up of the activities of reception, storage, handling of materials, inventories, vehicles, returns, among others.

b. Operations: composed of the transformation of the final product (machining, assembly, labeling, maintenance, verification and installation operations). c. Outbound logistics: consisting of the distribution of the finished product (storage of finished goods, material handling, delivery vehicles, orders and scheduling).

d. Marketing and sales: integrates the activities involved in the induction and easy acquisition of the products (advertising, sales force, quotas, channel selection, channel relations, prices).

e. Service: it consists of those activities that try to maintain and increase the value of the product after the sale (installation, repair, training, supply of spare parts and adjustment of the product).

To define the business support activities, the same criterion used in the definition of the main business actions is used, thus defining the following support activities:

a. Purchasing: made up of those activities involved in the acquisition of primary materials, supplies and consumables as well as assets.

b. Technology development: composed of those activities involved in the knowledge and training acquired, procedures and technological inputs required for each activity in the value chain.

c. Human resources management: composed of those activities involved in the selection, promotion and placement of the institution's personnel.

d. Institutional infrastructure: made up of those activities involved in general management, planning, information systems, finance, accounting, legal, government affairs and quality management. (Sanchez, 2006)

In competitive terms, value is the amount that buyers are willing to pay for what a company provides them; it reflects the scope of the product in terms of price and units that can be sold. A business is profitable if the value it imposes exceeds the costs involved in creating the product. Creating value for buyers that exceeds the cost of doing so is the goal of any generic strategy. Value, not cost, should be used in analyzing competitive position. (Deadline: 2019) 
The analysis of the value chain allows the optimization of the production process since it can be seen, in detail and at each step, the functioning of the company. The reduction of costs and the search for efficiency in the use of resources are usually the main objectives of the entrepreneur when reviewing the value chain. (Merino, 2012)

In the case of global value chains, large corporations take the lead in organizing the division of labor among participating companies, exercising greater or lesser control over the development of activities, structure, and dynamics of the chain. In turn, this leading role allows the large corporation to retain a greater portion of the total added value generated in the chain.

Following Humphrey and Schmitz (2002), four channels of improvement can be identified within global value chains:

1. Process improvement: implies efficiency gains in the transformation of inputs into outputs, thanks to the development or adoption of a superior technology or production system.

2. Product improvement: consists of the development of new, more sophisticated, or higher quality products that provide more usefulness/satisfaction to the consumer.

3. Functional improvement: it implies the assumption of new functions, in such a way that the knowledge content of the activity developed by the company is raised globally. In this way, the company can move from the mere assembly of imported components to the physical manufacture of and, from there, to assume the design or marketing of products under its brands.

4. Inter-sector or chain improvement: this consists of the abandonment by the company of the activity it had been carrying out in order to enter other sectors or other cvg, in which it has a greater capacity to generate and retain added value. (Luna, 2009)

The emergence of "Value Chains" as an organizational structure reflects the continuous evolution of the market economy, representing a marked change in the behavior of "management" and organizational strategies.
The value chain is created when companies have a shared vision and common goals. It is formed to bring together specific market objectives to meet the needs of consumers. This allows for joint decision making as well as the sharing of risks and benefits. It also allows for cooperative intelligence: cost structure, marketing, and organizational information are shared to increase the profit and competitiveness of the value chain. The value chain, therefore, provides the framework for conducting business transactions, responding to consumer needs; it implies trust and opens communication among its participants, and the results are mutually beneficial to all parties involved.

Value chain members will need to work on identifying and prioritizing business spaces, developing and implementing an action plan to respond to those spaces, and reviewing the results of the planning against objectives (Pearce, 1997). (Iglesias, 2002)

A supply chain is a set of elements that allow companies to have the necessary organization to carry out the development of a product or service and that this fulfills the main objective, which is to satisfy the needs of the final client.

The supply chain is a strategy and logistics that involves three parts or consists of three essential elements, which are: supply, manufacturing, and distribution.

Supply: this part refers to the raw materials with which the company works. It is essential to answer specific questions such as where the material comes from, how it is obtained, and the time it takes to get it to the places where it is required. If this step is not well taken care of, the whole chain will likely be affected, so it must work correctly.

Manufacturing: the phase of assembling or processing the product from the raw materials, to finally have a finished product.

Distribution: in this section, as its name indicates, the process of distributing the articles through a transport network, warehouses, premises, traders, to reach the final consumers. 
The supply chains can vary depending on the type of company we are talking about. These can be industrial, service, and marketing companies.

Industrial companies: they have a supply chain with great logistics, which will have different characteristics according to the size of the company, production lines, and public to which they direct their product. In it, we find the marketing, the development of new products, among other functions.

Service companies: they have hierarchical chains, that is, management, production, commercial, and distribution manager. They depend on human resources.

Marketing companies: they obtain and sell products, receive requests from customers, and are responsible for fulfilling them. (Arcia, 2017)

When we talk about the supply chain, we are referring to the union of all the companies involved in the production, handling, distribution, storage and marketing of a product and its components, in other words, it integrates all the companies that make it possible for a product to come to market at a given time. This includes raw material suppliers, manufacturers, distributors, transporters, and retailers.

The supply chain incorporates (in addition to logistics activities) other types of activities that are not directly linked in the field of logistics, that is, those support activities that are required for the optimal functioning of the organization, but that do not directly relate to the planning, manufacture, handling, storage, and distribution of the product. These support activities, according to Michael Porter, could include Human Resource Management, Technology, Infrastructure, Administration, and Maintenance, among others.

An indispensable requirement to achieve and reach a good Supply Chain Management process is, first, to make a good management process and logistic integration inside each company; it is not possible to pretend to reach high levels of performance on a global scale if each organization tolerates operational inefficiencies and does not make a good use of its processes and resources.
Therefore, the first step in the search for excellence in Supply Chain Management is to have a high level of performance in the internal logistics of companies, in which all logistics processes must be observed as interrelated and interdependent parts, in such a way that improvements are always sought that focus on the entire logistics process and not only on each particular element. (Gómez G. S., 2008)

The supply chain is based from the reception to the delivery to the final customer; that is, all the processes followed to reach the final product. These functions include, but are not limited to, the development of a new project, marketing, operations, distribution, finance, and service. The supply chain is contrasting, i.e., it involves a constant flow of information, products, and different points of view between personnel and the stages through which the product or service passes.

A supply chain can contain several stages, such as the following:

$\begin{array}{lll}- & \text { Clients } \\ - & \text { Retailers } \\ - & \text { Wholesalers and retailers } \\ - & \text { Manufacturers } \\ - & \begin{array}{l}\text { Suppliers of components and raw } \\ \text { materials }\end{array}\end{array}$

A supply chain is made up of all those parties directly or indirectly involved in satisfying a customer's request. The supply chain includes not only the manufacturer and the supplier but also the transporters, warehousemen, retailers (or retailers), and even the customers themselves. Within each organization, like the manufacturer, it encompasses all the functions involved in receiving and fulfilling a customer request. These functions include, but are not limited to, new product development, marketing, operations, distribution, finance, and customer service. The objective of a supply chain should be to maximize the total value generated. The value a supply chain generates is the difference between what the final product is worth to the customer and the costs the chain incurs to fulfill the customer's request. For most supply chains, the value will be closely correlated with the profitability of the supply chain (also known as supply chain surplus), which is the difference between the revenue generated by the customer and the total cost of the supply chain. (Peter, 2008)

RODRIGUEZ-AGUILAR, Raquel, GARCÍA-ROJAS, Jesús Alberto, CRUZ-ÁLVAREZ, Arminda and LÓPEZ-HERNÁNDEZ, Karla Linive. Development of the value chain and supply chain for MiPymes of the municipality of Mixquiahuala de Juárez Hidalgo to generate networks of mutual collaboration. Journal of Bussines and SMEs. 2019. 
Supply Chain Management is nothing other than the management system that establishes and controls the supply chain, a system that cannot be the traditional authoritarian one, but must be a system that contemplates all the components of the chain in all its magnitude and manages the chain as a whole, achieving the absolute involvement of all its components. The objective should be to seek the benefit for the whole chain and, starting from the whole, to reach the individual benefits of each of the links, contrary to the traditional model, in which each component sought the benefits individually.

If these premises are fulfilled, the application of knowledge management models to the supply chain will, in principle, be feasible. Supply Chain Management is nothing other than the management system that establishes and controls the supply chain, a system that cannot be the traditional authoritarian one, but must be a system that contemplates all the components of the chain in all its magnitude and manages the chain as a whole, achieving the absolute involvement of all its components. The objective should be to seek the benefit for the whole chain and, starting from the whole, to reach the individual benefits of each of the links, contrary to the traditional model, in which each component sought the benefits individually. If these premises are fulfilled, the application of knowledge management models to the supply chain will, in principle, be feasible. (CapóVicedo \& Expósito-Langa, 2007)

\section{Methodology to be developed}

In this developmental phase, the impact of obtaining data on the time and emotional state of the student will be reflected, directly impacting the results. In addition to using the quantitative and qualitative method with the application of surveys in order to know the opinions of different students (Figure 1).

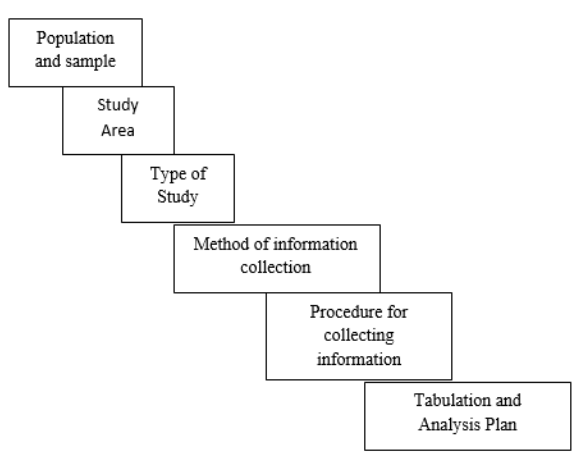

Figure 1 Procedure for the quantitative analysis of information Source: Prepared by the authors

Table 1 shows the total number of businesses surveyed per colony in the Municipality of Mixquiahuala de Juárez, Hgo., where it is observed that the largest population assisted for this research was the neighborhood called Centro, which has the largest population.

\begin{tabular}{|c|c|c|c|c|c|c|}
\hline & Reforma & Teñhe & $\begin{array}{c}\text { El } \\
\text { Danfhi }\end{array}$ & $\begin{array}{c}\text { La } \\
\text { Estación }\end{array}$ & $\begin{array}{c}\text { El } \\
\text { Centro }\end{array}$ & $\begin{array}{c}\text { El } \\
\text { Calvario }\end{array}$ \\
\hline Bakeries & 1 & 2 & 1 & 4 & 13 & 6 \\
\hline Purifiers & 0 & 1 & 0 & 0 & 0 & 0 \\
\hline Tortilla shops & 7 & 8 & 3 & 4 & 13 & 10 \\
\hline Groceries & 18 & 32 & 11 & 17 & 68 & 40 \\
\hline $\begin{array}{l}\text { greengrocer's } \\
\text { shop }\end{array}$ & 2 & 2 & 0 & 1 & 15 & 3 \\
\hline Poultry shops & 9 & 3 & 0 & 4 & 16 & 4 \\
\hline Butcher shops & 4 & 5 & 0 & 1 & 17 & 5 \\
\hline Others & 0 & 0 & 0 & 0 & 0 & 0 \\
\hline & 41 & 53 & 15 & 31 & 142 & 68 \\
\hline
\end{tabular}

Table 1 Neighborhoods surveyed in Mixquiahuala, Hgo Source: Prepared by the authors

Table 2 shows the continuation of businesses surveyed in the municipality of Mixquiahuala de Juárez, Hgo., noting that the Taxhuada neighborhood is the largest, since it is the second most populated within the municipality.

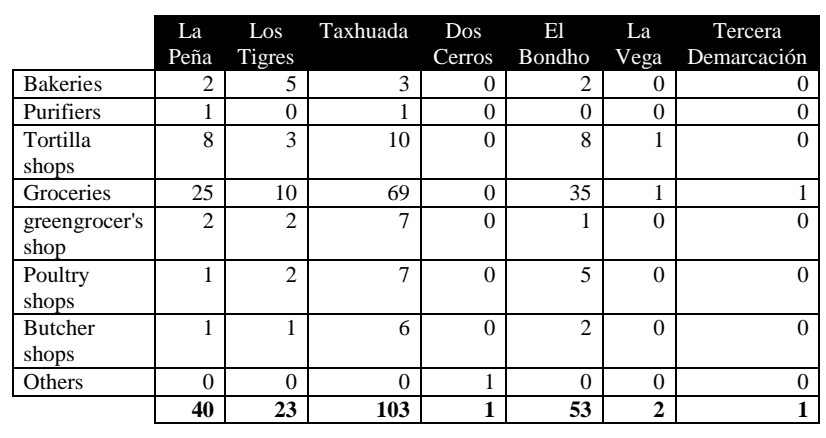

Table 2 Neighborhoods surveyed in Mixquiahuala, Hgo Source: Prepared by the authors 


\section{Results Analysis of the surveys}

\section{Stationery stores}

How many years have you been offering your products or service?

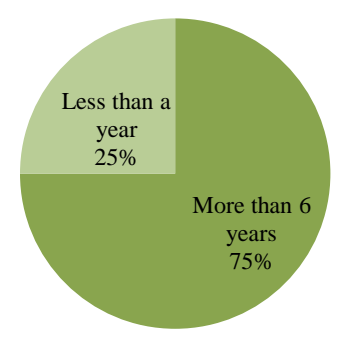

Figure 2 Stationery question 1

Source: Prepared by the authors

Figure 2 shows that the response obtained is focused with the antiquity of the business and we obtained that most of the businesses are more than 6 years old.

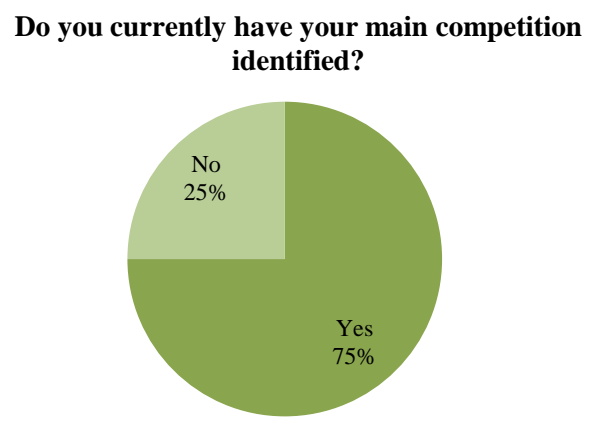

Figure 3 Question 2 on stationery

Source: Prepared by the authors

Figure 3 shows that most owners know who their main competition is.

Do you think you have been affected in your sales
by the presence of large supermarkets or shopping centres in your area?

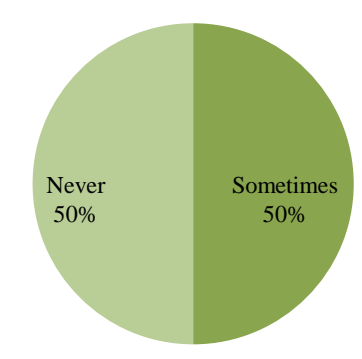

Figure 4 Question 3 on stationery Source: Prepared by the authors
Figure 4 shows that half of the businesses have experienced a great impact from large supermarkets or shopping centers because sometimes their sales decrease, however $50 \%$ say that the businesses are not affected by the fact that there are such companies around them.

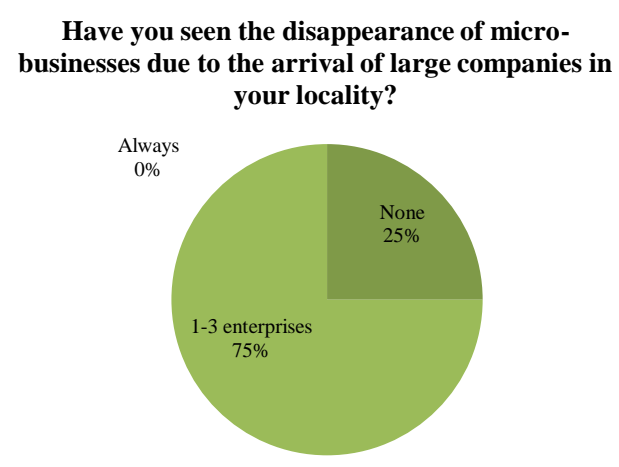

Figure 5 Stationery question 4

Source : Prepared by the authors

Figure 5 shows that with the arrival of large companies, more than $70 \%$ of businesses have only disappeared in one to three microenterprises, that is, the arrival of large companies does not directly affect microenterprises.

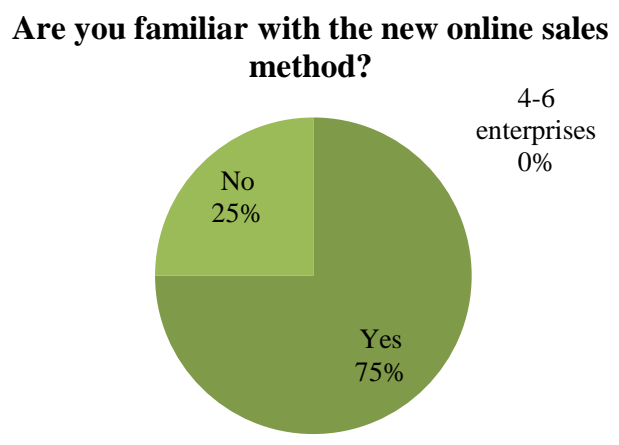

Figure 6 Stationery question 5 Source: Prepared by the authors

Figure 6 shows that more than $70 \%$, i.e. most of the businesses surveyed, are aware of this modality.

\section{Do you currently have internet service?}

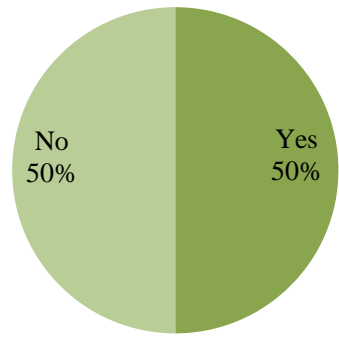

Figure 7 Stationery question 6

Source: Prepared by the authors

RODRIGUEZ-AGUILAR, Raquel, GARCÍA-ROJAS, Jesús Alberto, CRUZ-ÁLVAREZ, Arminda and LÓPEZ-HERNÁNDEZ, Karla Linive. Development of the value chain and supply chain for MiPymes of the municipality of Mixquiahuala de Juárez Hidalgo to generate networks of mutual collaboration. Journal of Bussines and SMEs. 2019. 
Figure 7 shows that the online market still needs to be spread, as only half of the traders have purchased a product by this means.

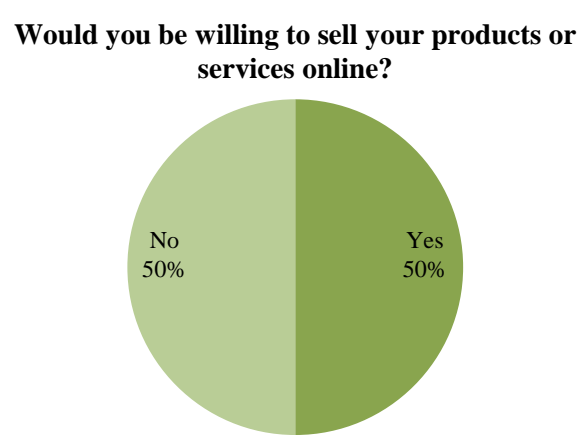

Figure 8 Stationery question 7

Source: Prepared by the authors

Figure 8 shows that half of the merchants are not willing to sell their products online, this is due to the belief that online trading is not efficient, as well as being very complex at the time of selling, while the other half of the merchants are willing to sell online as they consider it to be an effective way of marketing their products.

\section{Have you purchased any products or services online?}

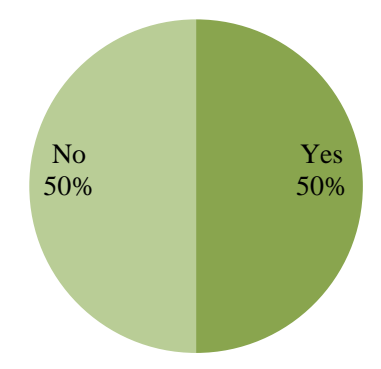

Figure 9 Stationery question 8

Source: Prepared by the authors

Figure 9 shows that half of the businesses have internet service, while the other half of the businesses do not have this service for different reasons, one of them being their socioeconomic level.

Would you like to learn more about online sales?

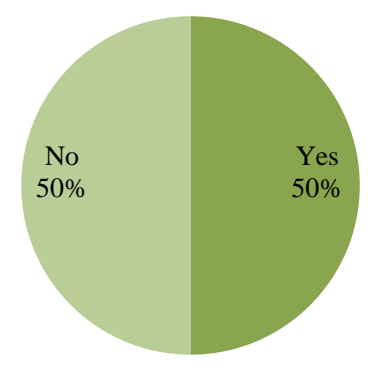

Figure 10 Stationery question 9

Source: Prepared by the authors
Figure 10 shows that half of the businesses are not interested in knowing the modality of online sales, since they are businesses that are still closed to opportunities or in their case due to lack of capital, while the other half are interested in knowing this modality because they are aware that it is an opportunity to increase their sales in the market. Tortilla shops

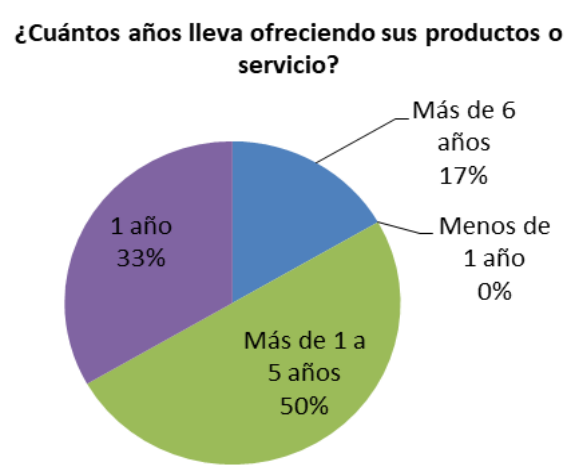

Figure 11 Question 1 tortilla shops Source: Prepared by the authors

Figure 11 shows the antiquity of the businesses, and one of the outstanding data is that half of them have been offering their products for 1 to 5 years.

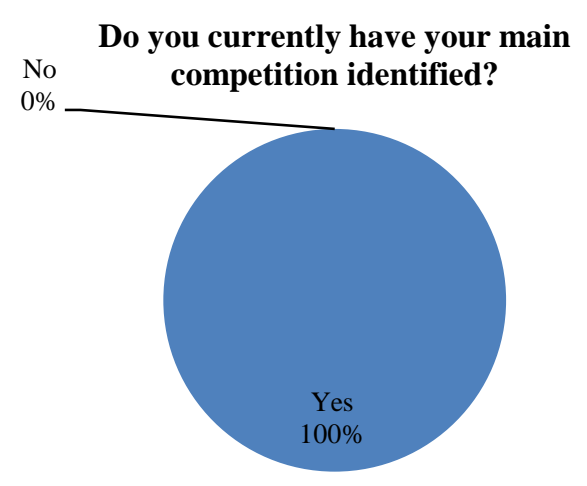

Figure 12 Question 2 tortilla shops

Source: Prepared by the authors

Figure 12 shows that all traders are aware of their main competition and the strengths they possess.
RODRIGUEZ-AGUILAR, Raquel, GARCÍA-ROJAS, Jesús Alberto, CRUZ-ÁLVAREZ, Arminda and LÓPEZ-HERNÁNDEZ, Karla Linive. Development of the value chain and supply chain for MiPymes of the municipality of Mixquiahuala de Juárez Hidalgo to generate networks of mutual collaboration. Journal of Bussines and SMEs. 2019. 


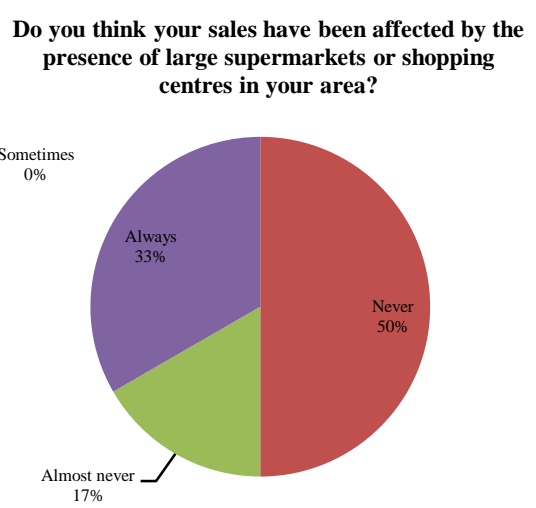

Figure 13 Question 3 tortilla shops Source: Prepared by the authors

Figure 13 shows that slightly more than a third of traders were affected by the arrival of large shops or supermarkets, while the other half claim to have had no damage to their sales or any impact.

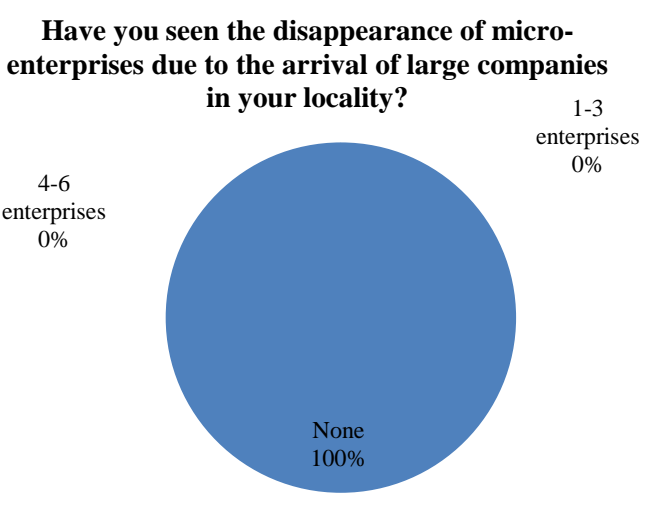

Figure 14 Question 4 tortilla shops

Source: Prepared by the authors

Figure 14 shows that a MSME has never disappeared from the locality due to the appearance of large companies.

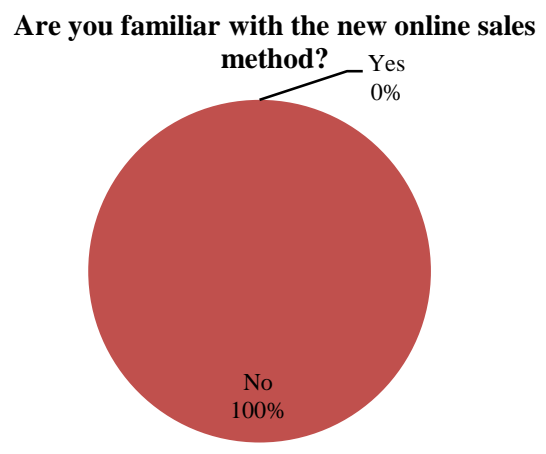

Figure 15 Question 5 tortilla shops Source: Prepared by the authors

Figure 15 shows that tortilla merchants have no idea about online sales.
Have you purchased/contracted any

products or services online?

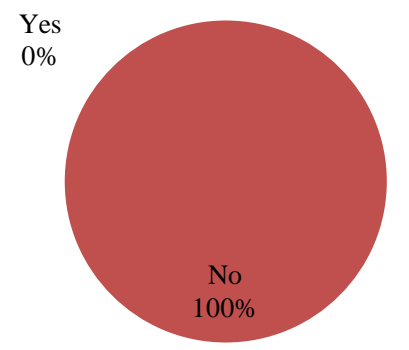

Figure 16 Question 6 tortilla shops Source: Prepared by the authors

Figure 16 shows that no merchant has ever purchased or contracted for a product online.

Would you be willing to sell your products or services online?

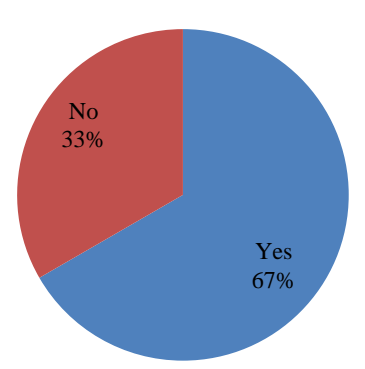

Figure 17 Question 7 tortilla shops Source: Prepared by the authors

Figure 17 shows that this result is a consequence of their mistrust of collaborative networks as well as online sales, but they would be willing to learn more from it in order to market their products.

\section{Do you currently have internet service?}

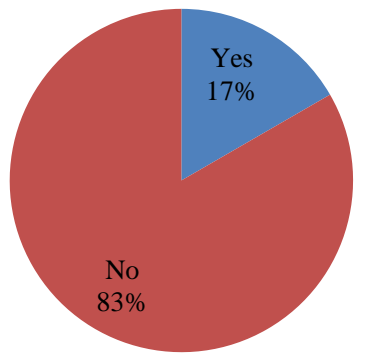

Figure 18 Question 8 tortilla shops Source: Prepared by the authors

Figure 18 shows that more than $80 \%$ of merchants do not have internet service, but would be willing to have it to improve their profits. 
Would you like to learn more about online sales?

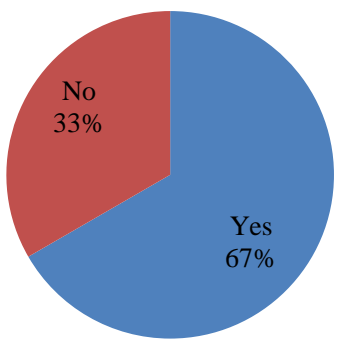

Figure 19 Question 9 tortilla shops

Source: Prepared by the authors

Figure 19 shows that although the vast majority of merchants are not aware of online services, they are willing to learn more about them in order to use them as a sales tool and multiply their profits.

\section{Butcher shops}

How many years have you been offering your products or service?

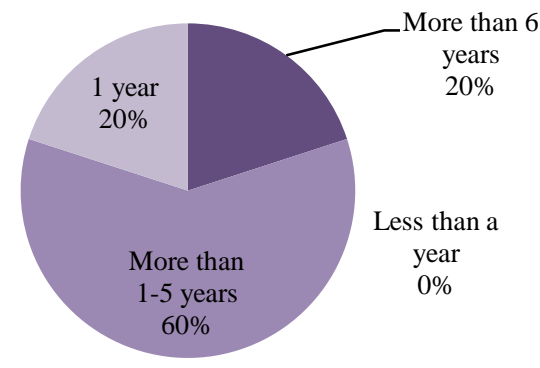

Figure 20 Question 1 Butchers

Source: Prepared by the authors

Figure 20 shows that more than $50 \%$ of the butchers in the municipality of Mixquiahuala have been offering their products and/or services for more than 1 year up to 5 years, which indicates that they have been in the market for some time.

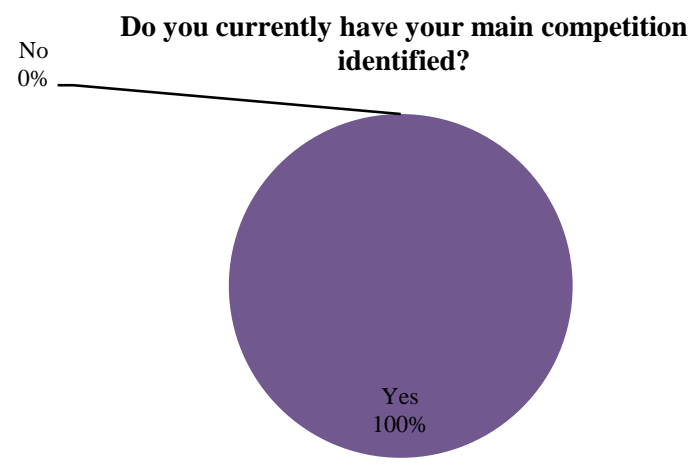

Figure 21 Question 2 Butchers Source: Prepared by the authors
Figure 21 shows that all the businesses surveyed in Mixquiahuala have currently identified their main competition in the market.

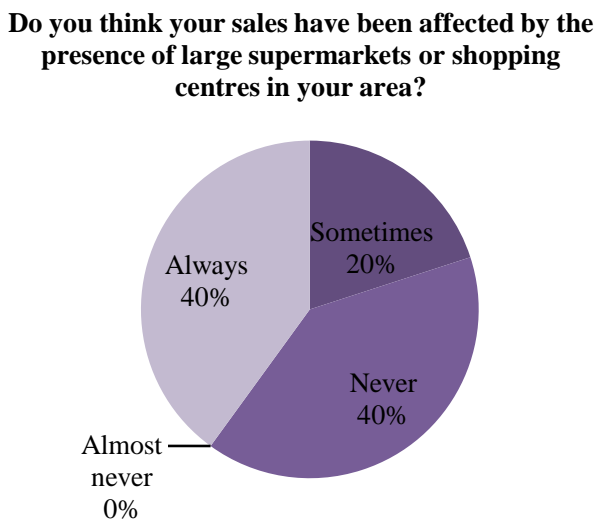

Figure 22 Question 3 Butchers Source: Prepared by the authors

In Figure 22 the responses show that at least $40 \%$ of businesses are never affected by the presence of large supermarkets, while the other $40 \%$ say that they are always affected, since people prefer to buy their products either for price or convenience, while the remaining $40 \%$ say that sometimes they are affected and that is reason enough for their sales to decrease.

\section{Have you seen the disappearance of micro-enterprises due to the arrival of large companies in your locality?}

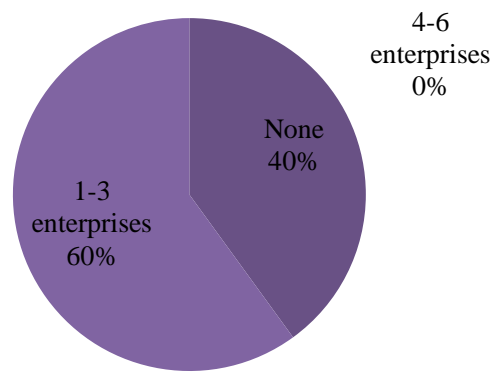

Figure 23 Question 4 Butchers Source: Prepared by the authors

Figure 23 shows that the majority of businesses indicate that at least 1 to 3 microenterprises disappear due to the arrival of large companies, which means that the arrival of these directly affects those existing in their environment. 
Are you familiar with the new online sales method?

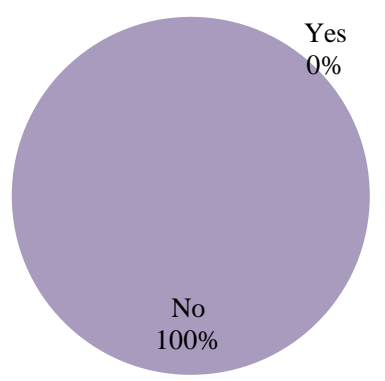

Figure 24 Question 5 Butchers Source: Prepared by the authors

Figure 24 shows that none of the businesses that were surveyed know how to sell products and/or services online.

\section{Have you purchased any products or services online?}

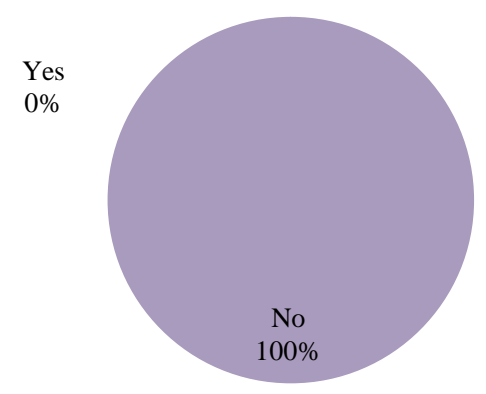

Figure 25 Question 6 Butchers

Source: Prepared by the authors

Figure 25 shows that none of the businesses that were surveyed have purchased or contracted any type of product or service online, because they do not trust such networks, they think it is a very difficult way to acquire it.

\section{Would you be willing to sell your products or services online?}

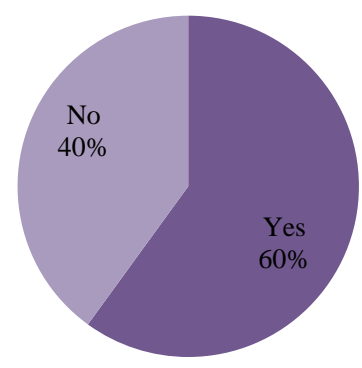

Figure 26 Question 7 Butchers

Source: Prepared by the authors
Figure 26 shows that most businesses are willing to sell their products and/or services over the Internet as it is a new way to increase their sales, satisfying the customer in an efficient way.

\section{Do you currently have internet service?}

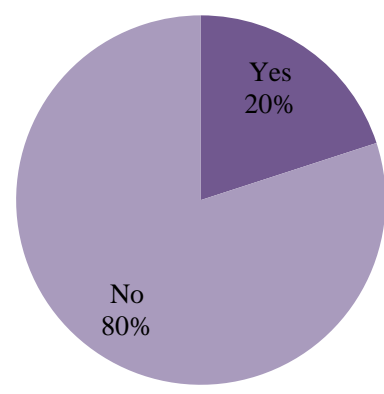

Figure 27 Question 8 Butchers Source: Prepared by the authors

Figure 27 shows that more than $75 \%$ of businesses do not have Internet service, mainly due to lack of capital in microenterprises, or simply due to lack of knowledge about technology, while $20 \%$ do have Internet service since they consider it an indispensable tool for day-to-day improvement.

\section{Would you like to learn more about online sales?}

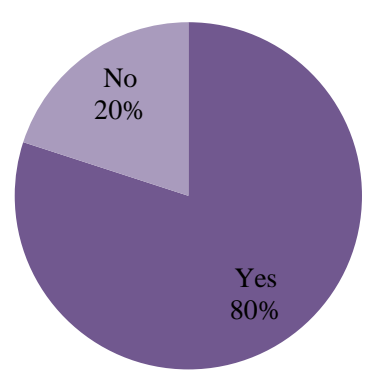

Figure 28 Question 9 Butchers

Source: Prepared by the authors

Figure 28 shows that at least $80 \%$ of the microenterprises are interested in learning more about the online sales modality since they know that this can have a positive change for their businesses, while the remaining ones would not like to know, for fear of change. 


\section{Groceries}

How many years have you been offering your products or service?

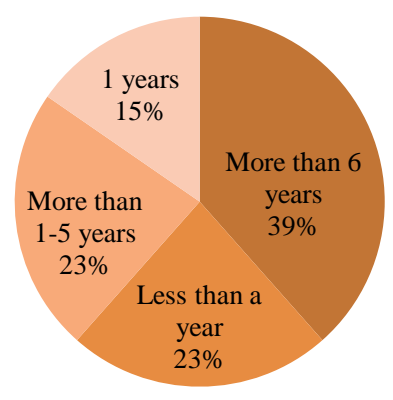

Figure 29 Question 1 Groceries

Source: Prepared by the authors

Figure 29 shows that more than $30 \%$ of microenterprises have been offering their products on the market for more than 6 years, this being the most relevant data.

\section{Do you currently have your main} competition identified?

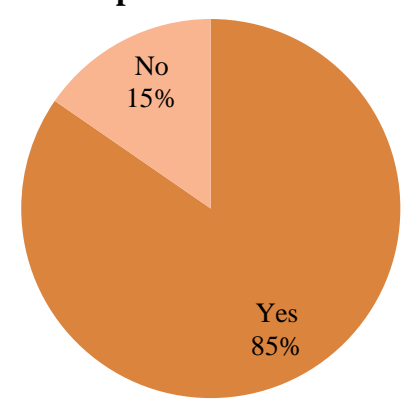

Figure 30 Question 2 Groceries

Source: Prepared by the authors

Figure 30 shows in the above graph that most traders have well identified their main competition.

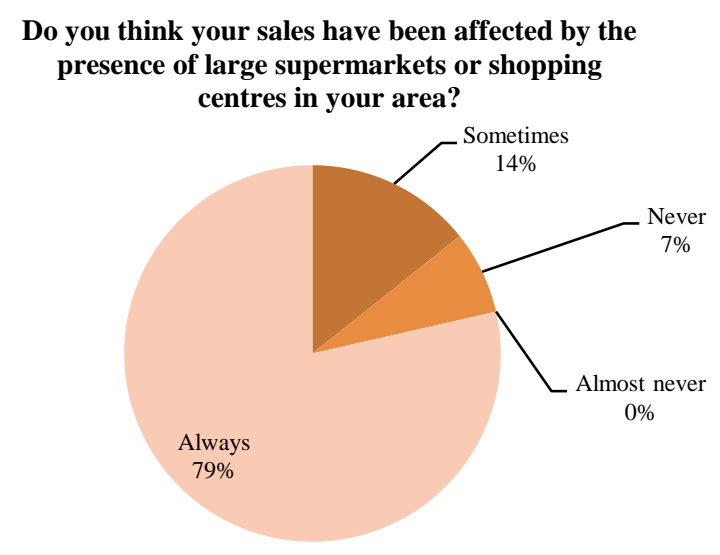

Figure 31 Question 3 Groceries Source: Prepared by the authors
Figure 31 shows that as a result, more than $70 \%$ of traders claim to be affected in their sales as a result of the arrival of large supermarkets.

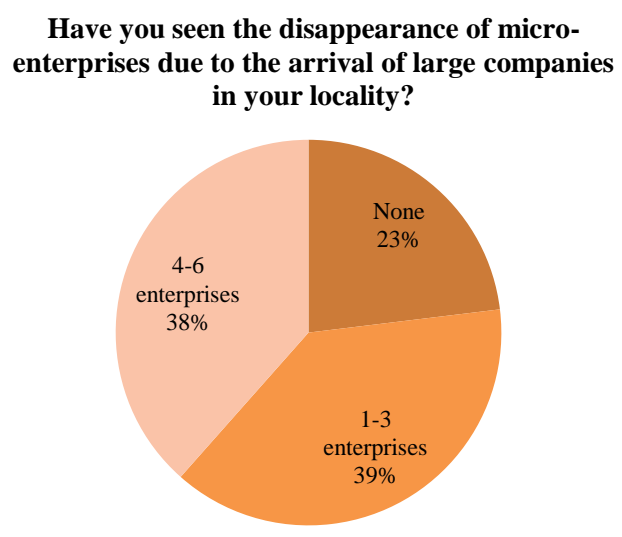

Figure 32 Question 4 Groceries Source: Prepared by the authors

Figure 32 presents data that at least 39\% say they have seen 1 to 3 MSEs disappear due to the arrival of the supermarkets, while $38 \%$ say they have seen 4 to 6 disappearances, being two of the most relevant data.

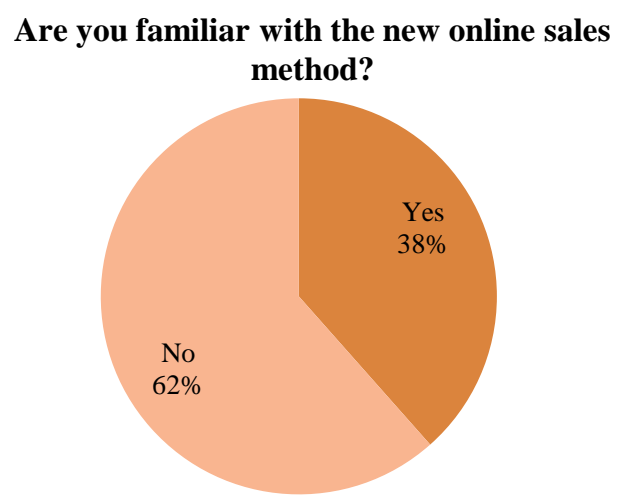

Figure 33 Question 5 Groceries Source: Prepared by the authors

Figure 33 shows that the vast majority of grocery stores in Mixquiahuala say they have no idea about online sales.

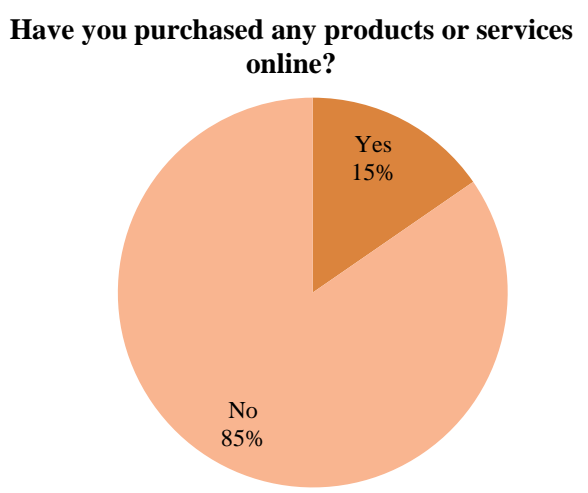

Figure 34 Question 6 Groceries Source: Prepared by the authors

RODRIGUEZ-AGUILAR, Raquel, GARCÍA-ROJAS, Jesús Alberto, CRUZ-ÁLVAREZ, Arminda and LÓPEZ-HERNÁNDEZ, Karla Linive. Development of the value chain and supply chain for MiPymes of the municipality of Mixquiahuala de Juárez Hidalgo to generate networks of mutual collaboration. Journal of Bussines and SMEs. 2019. 
Figure 34 shows that as a result of the previous question, to which it refers that they have no knowledge of online sales, they indicate that they have never purchased in this mode.

\section{Would you be willing to sell your products or services online?}

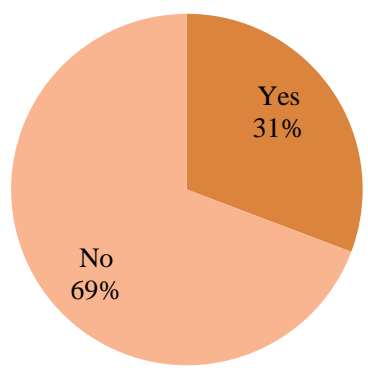

Figure 35 Question 7 Groceries

Source: Prepared by the authors

Figure 35 shows that most grocery merchants in Mixquiahuala are not interested in selling their products online.

\section{Do you currently have internet service?}

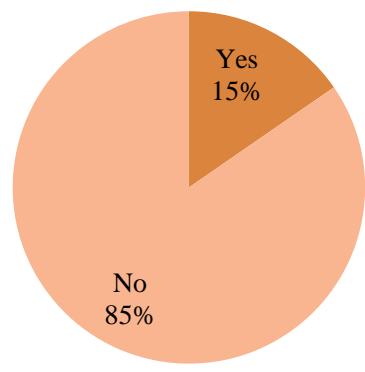

Figure 36 Question 8 Groceries

Source: Prepared by the authors

Figure 36 shows that over $80 \%$ of merchants, i.e. the vast majority of businesses, do not have internet service.

\section{Backeries}

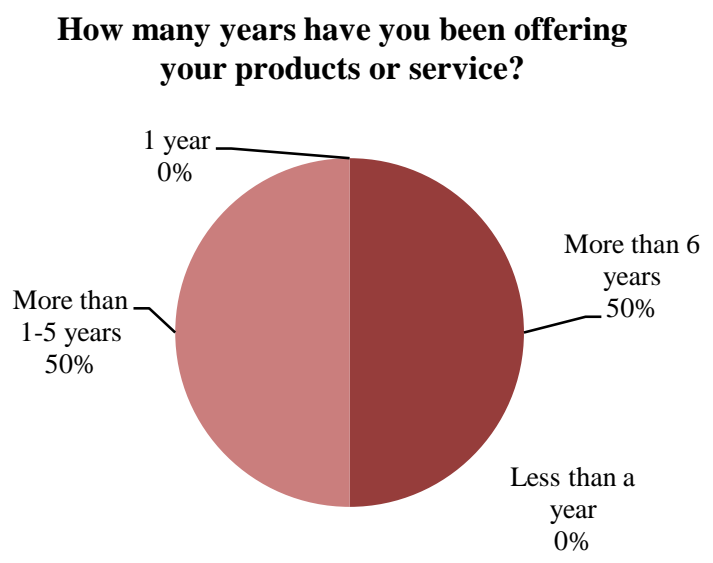

Figure 37 Question 1 Bakeries

Source: Prepared by the authors
Figure 37 shows that half of the bakers have been in business from 1 to 5 years, and the other half are over 6 years, i.e., the years are high considering the parameters compared to the others.

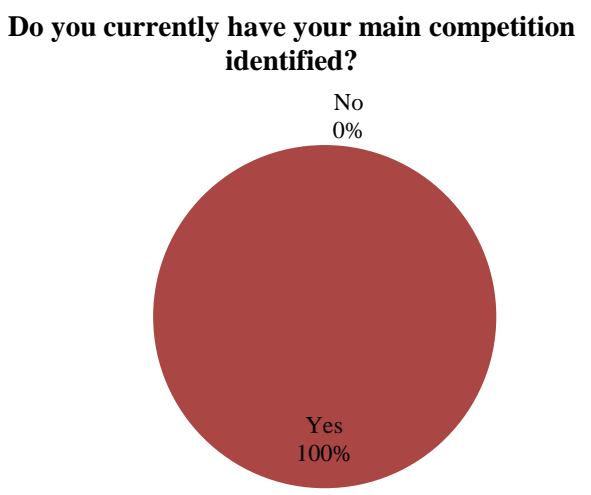

Figure 38 Question 2 Bakeries

Source: Prepared by the authors

Figure 38 shows that, as in the previous answers, all traders have identified their main competences.

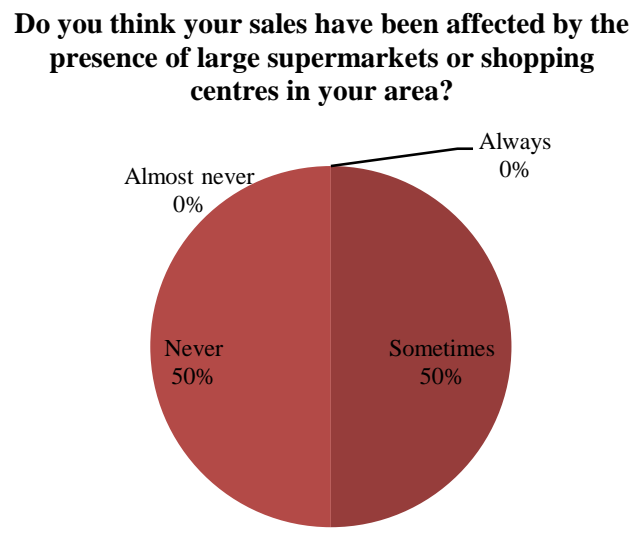

Figure 39 Question 3 Bakeries

Source: Prepared by the authors

Figure 39 shows that half of the bakers claim to have been affected by the appearance of the shopping centres, while the other half claim to have had no effect on their sales.

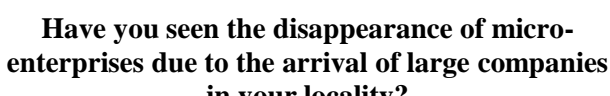
enterprises due to the arrival of large companies

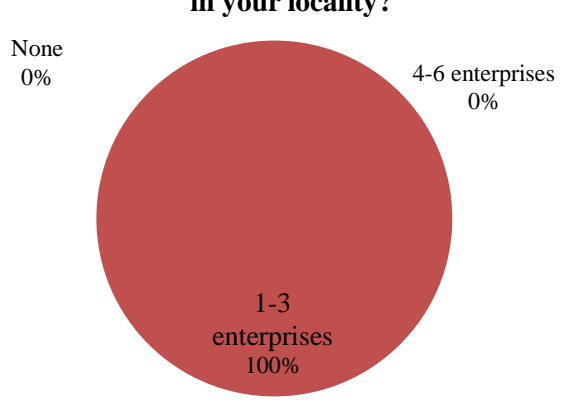

Figure 40 Question 4 Bakeries

Source: Prepared by the authors

RODRIGUEZ-AGUILAR, Raquel, GARCÍA-ROJAS, Jesús Alberto, CRUZ-ÁLVAREZ, Arminda and LÓPEZ-HERNÁNDEZ, Karla Linive. Development of the value chain and supply chain for MiPymes of the municipality of Mixquiahuala de Juárez Hidalgo to generate networks of mutual collaboration. Journal of Bussines and SMEs. 2019. 
Figure 40 shows that all the bakers have seen the disappearance of at least 3 companies as a result of the shopping centres that have been installed in Mixquiahuala.

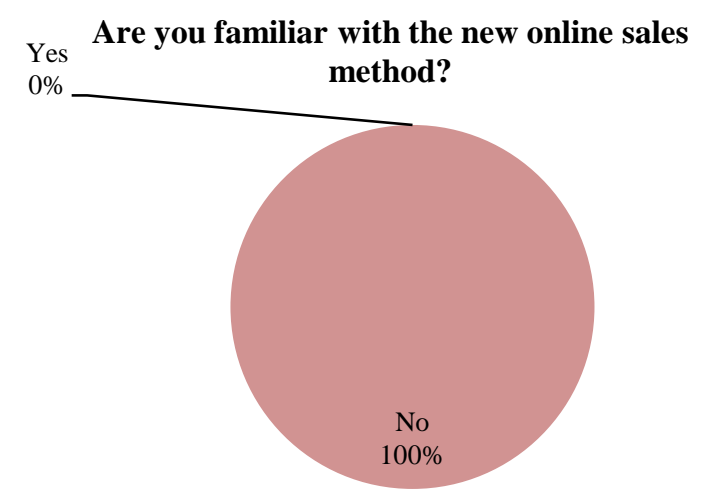

Figure 41 Question 5 Bakeries

Source: Prepared by the authors

In Figure 41 the results show that none of the bakers in the municipality of Mixquiahuala know anything about selling online.

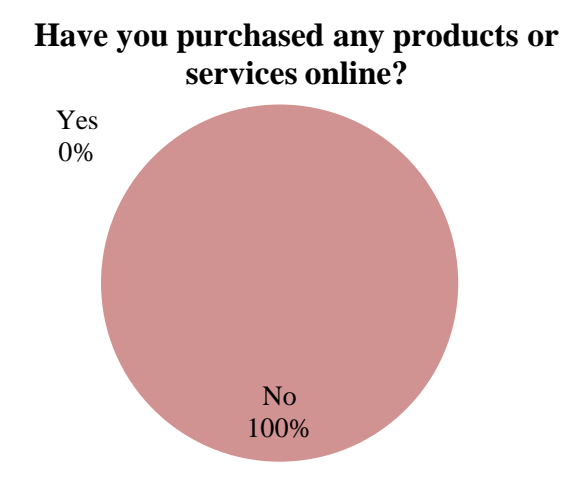

Figure 42 Question 6 Bakeries

Source: Prepared by the authors

Figure 42 shows that as a consequence of not having knowledge about selling online, they have never bought in this modality.

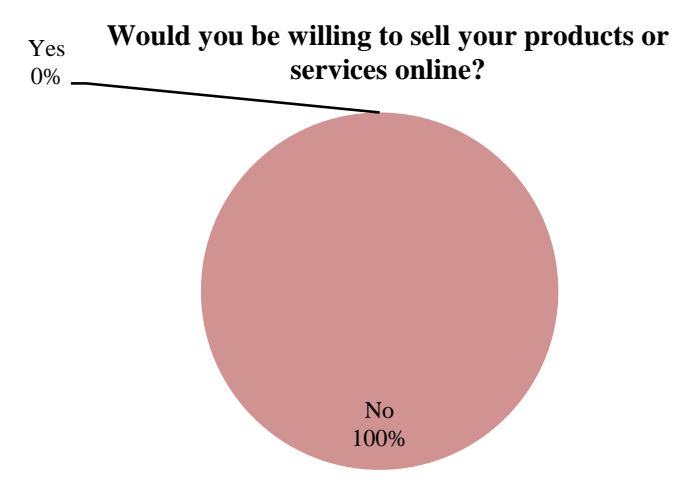

Figure 43 Question 7 Bakeries

Source: Prepared by the authors
Figure 43 shows that none of the bakers are interested or willing to sell their products online.

Do you currently have internet service?

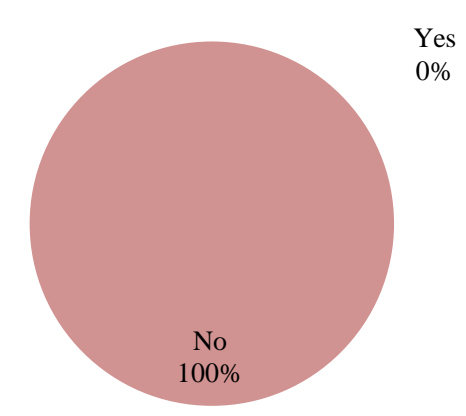

Figure 44 Question 8 Bakeries

Source: Prepared by the authors

Figure 44 shows that none of the merchants have Internet service, either because their possibilities do not allow it or because they are not interested in it.

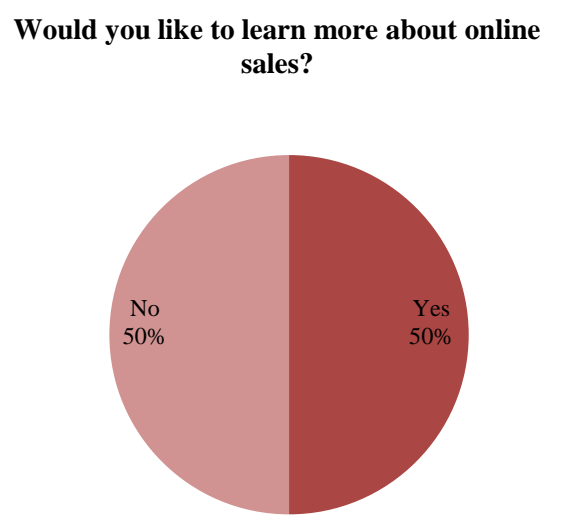

Figure 45 Question 9 Bakeries

Source: Prepared by the authors

Figure 45 shows that half of the bakers are interested in knowing more about this modality for its implementation, it is worth mentioning that the other half does not show the same interest. 


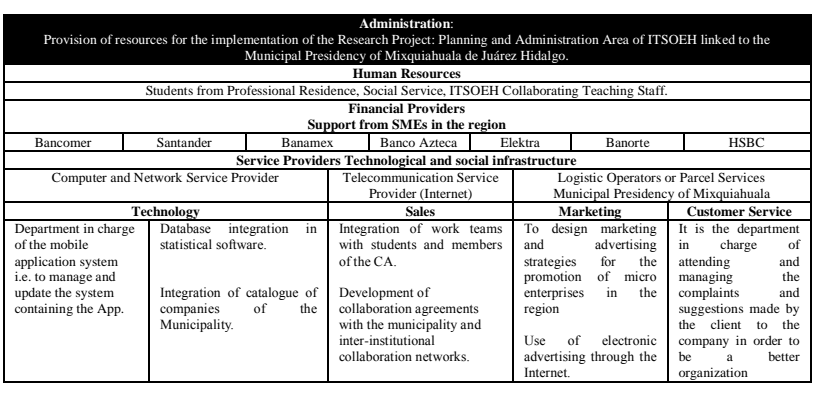

Figure 46 Value Chain Model Source: Prepared by the authors

Figure 46 shows the value chain model which is made up of the main areas that help improve the mobile application and better performance inside and outside the organization, which are management, human resources, financial suppliers, technology, sales, marketing and customer service.

\section{Supply Chain}

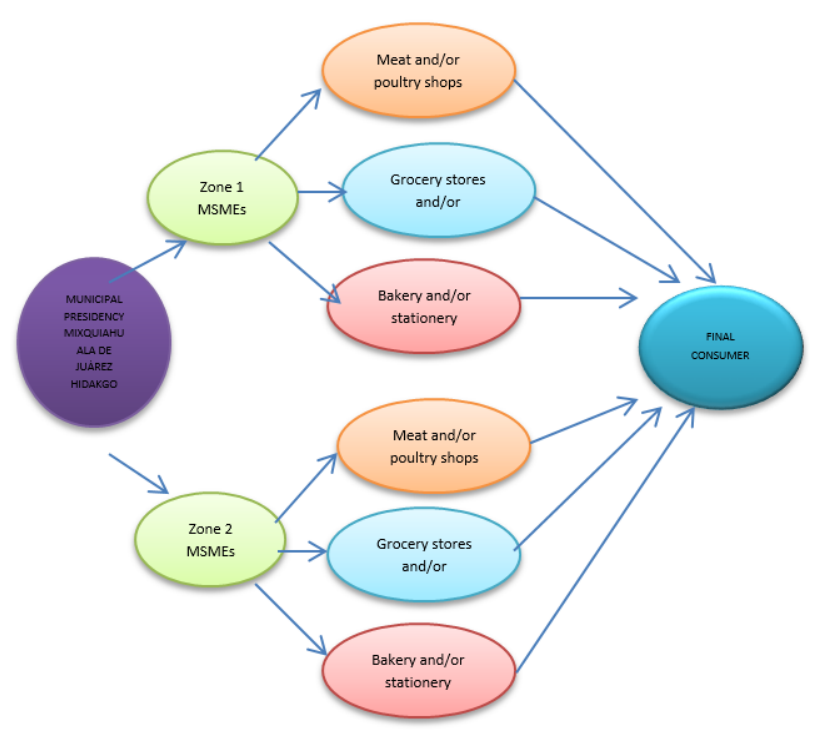

Figure 47 Supply Chain Model

Source: Prepared by the authors

Figure 47 shows that the supply chain is fundamental concerning the value chain, although they are linked. The supply chain is responsible for distributing the products through a network of facilities whose function is to obtain materials and thus distribute them so that they reach the end consumer, without leaving aside the fact that the product has to arrive on time and in the correct form, thus satisfying their needs.
That is why the supply chain for the distribution of the product was designed in this way because in the municipal presidency will be located the office receiving data so that the distributors arrive at the place to receive the receipts of the sale that will be made to continue with the main process of the network of collaboration SMEs ONLINE; therefore will be classified by area of the Municipality of Mixquiahuala de Juarez Hidalgo.

Main process of the collaborative network

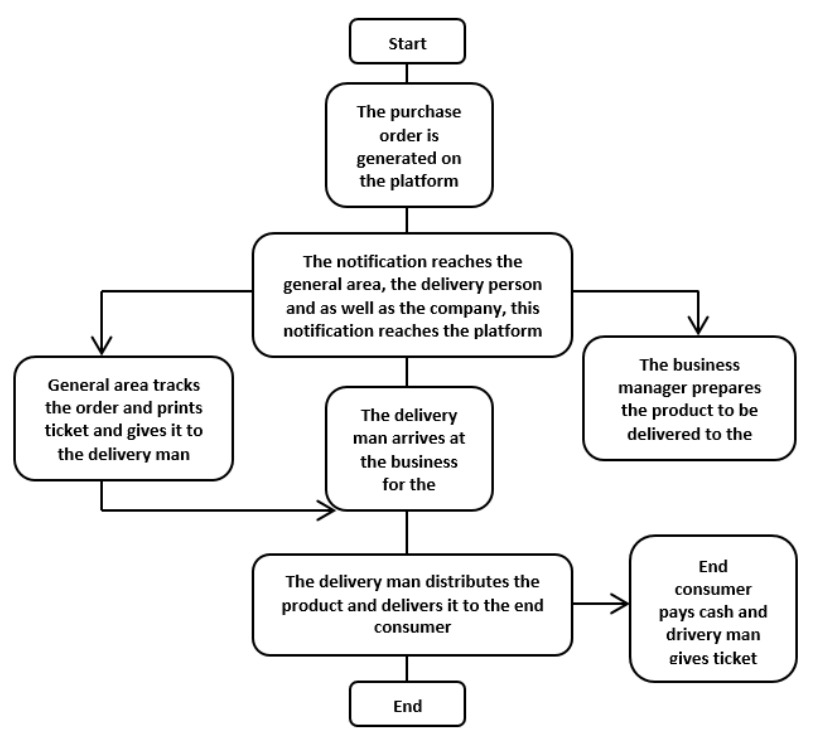

Figure 48 Main process of the collaborative network Source: Prepared by the authors

Figure 48 shows the process that the collaboration network will follow, that is, the steps that will make up the steps from the time the purchase order is generated, through the notifications that alert the orders, and the areas that intervene within them, as well as the human and material resources required to provide the complete service to each customer.

When analyzing the surveys conducted among the MSEs in the municipality of Mixquiahuala de Juárez, Hgo. of the different lines of business (stationery stores, tortilla shops, butcher shops, grocery stores and bakeries) it was found that most of them have a market presence of between one and five years and even more than six years, as well as most of the merchants have their competitors well identified which in turn allows them to see both their strengths and the level of presence in the market. 
Also the arrival of large companies, in one way or another, has affected them, resulting in reduced sales which generate losses; on the other hand, the results show that there is also the disappearance of the MSEs thanks to the arrival of large companies, as well as is reflected the little knowledge of selling online, usually because there is no knowledge of this mode; purchases or some hiring of services or products online is usually zero, as for the disposition of the different merchants of the municipality is usually present due to different causes, either because they want to increase their profits or because they do not want to leave the market so easily, which is why they mostly prefer not to hire some type of service that offers internet.

It should be mentioned that most shop owners are older people; therefore, they do not have the same ideology as younger people, but once raised the situation, they were interested in this new implementation and although the road is long for its completion, they are in the best disposition to learn to use these networks of collaboration in order to increase their sales.

It is said that there is a horizontal structure, which means that leadership is of great importance since it is not imparted nor much less submitted, but rather that decisions are made together, taking into account the common goal always seeking the joint benefit, reaching greater productivity. Therefore, it is very important to implement collaboration networks, since leadership is formed mainly by work team, formed by the benefactor institution that supports the MSEs of the municipality of Mixquiahuala de Juárez Hidalgo, being the Municipal Presidency who has supported this Application project, in order to increase the sales of the MSEs of the municipality.

Figure 49 below shows the distribution channels that will help in this application, which will be the following, seeking to reduce both time and expenses, thus increasing the profits of each of the components of this channel.

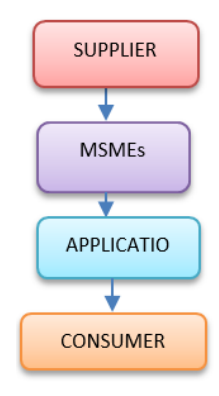

Figure 49 Distribution channels

The distribution of the products based on the application once the orders have been made will be divided from the moment of requisition to the different merchants according to the customer's order, in turn promoting delivery to the customer's home, taking into account it as a competitive advantage, through the use of motorcycles for delivery, in order to reduce costs knowing that it is a means of transport that does not exhaust the fuel as quickly as others, which will generate fewer costs. Continuing with the characteristics that this application will have, it is worth mentioning that the payment will be made according to the needs of the clients since there will be two forms of payment:

The first will be in cash, making this payment at the time of delivery of the product.

- The second will be by electronic payment (debit or credit card).

Finally, once it has been delivered to the final client or consumer, the implementation of the product will be finished, and therefore the purpose will have been fulfilled.

\section{Conclusions}

In conclusion, this application will be to support the MSEs of the municipality of Mixquiahuala de Juárez Hidalgo, since it is an innovative instrument seeking that all collaborate to increase their sales and to reduce or to eliminate competitiveness among the MSEs of the area, taking advantage of the enormous impact of technology, not only to use it as a distraction but occupying its benefits to grow the market and to obtain a competitive advantage of the ICTs. The collaboration networks are structured by a team, so all the MSEs that wish to belong to this project must be motivated and oriented towards a common objective, without considering as rivals other micro-enterprises.

RODRIGUEZ-AGUILAR, Raquel, GARCÍA-ROJAS, Jesús Alberto, CRUZ-ÁLVAREZ, Arminda and LÓPEZ-HERNÁNDEZ, Karla Linive. Development of the value chain and supply chain for MiPymes of the municipality of Mixquiahuala de Juárez Hidalgo to generate networks of mutual collaboration. Journal of Bussines and SMEs. 2019. 
But as an opportunity to make their business grow, with the purpose that all march towards the same objective, the one to increase their profits and to have a more objective vision on the ICT, beginning with few companies and to support with training, and that they are in the best disposition to even acquire a mobile phone, which can work with mobile data.

\section{References}

Arcia, M. (July 17, 2017). Entrepeneur. Recovered on August 07, 2019, from https://www.entrepreneur.com/article/316908

Capó-Vicedo, J., \& Expósito-Langa, J. V.-M. (2007). La Gestión del Conocimiento en la Cadena de Suministro. Análisis de la Influencia del Contexto Organizativo. Información tecnológica, 127-136.

Cordero, A. T. (2009). UAEH. Recovered on 07/08/2019, from https://www.uaeh.edu.mx/investigacion/product os/4830/las_micro_pequenas_y_medianas.pdf

Gómez, G. S. (2008). Cuantificación de valor en la cadena de suministro extendida. En G. S. Gómez, Cuantificación de valor en la cadena de suministro extendida (págs. 12-15). Del Blanco Editores.

Gómez, V. (2007). Recovered on July 30, 2019, from

https://s3.amazonaws.com/academia.edu.docum ents/44452942/559-1735-1-PB.pdf?responsecontent-

disposition=inline \%3B\%20filename\%3DComp etitividad_Para_Las_Micro_Pequenas_y.pdf \&X -Amz-Algorithm=AWS4-HMAC-SHA256\&XAmz-

Credential=AKIAIWOWYYGZ2Y53UL3A $\% 2$ F20190730\%2

H., R. R. (2007). Las MiPYMES en Latinoamerica. En R. R. H., Las MiPYMES en Latinoamerica (pág. 277). EUMED.

Iglesias, D. H. (Febrero de 2002). CADENAS DE VALOR COMO ESTRATEGIA:LAS CADENAS DE VALOR EN EL SECTOR AGROALIMENTARIO. Recovered on 09 2019, from Estación Experimental Agropecuaria Anguil: https://inta.gob.ar/sites/default/files/script-tmpcadenasdevalor.pdf
Luna, I. R. (2009). Pymes y cadenas de valor globales.Implicaciones para la política industrial. Redalyc.org, 199-216.

Merino, J. P. (2012). Definicion.de: Definición de cadena de valor. Recovered on August 07, 2019, from Definicion.de: Definición de cadena de valor : https://definicion.de/cadena-de-valor/

Peter, C. S. (2008). Administración de la cadena de suministro . Mexico : Pearson. Prentice Hall.

Plazoala, F. O. (2019). Cadena de Valor. Estrategia Magazine, 1-3.

Robben, X. (2015). La cadena de valor de Michael Porter. En X. Robben, La cadena de valor de Michael Porter (págs. 6-8). Mexico: 50 Minutos.

Sánchez, J. Q. (2006). La cadena de valor: Una herramienta del pensamiento estratégico . Redalyc.org, 377-389. 